\title{
ADDITÍV GYÁRTÁSTECHNOLÓGIÁK KATONAI ALKALMAZÁSÁNAK VIZSGÁLATA, KÜLÖNÖS TEKINTETTEL A KATONAI ELEKTRONIKA TERÜLETÉRE
}

\section{ANALYSIS OF MILITARY APPLICATIONS OF ADDITIVE MANUFACTURING TECHNOLOGIES, WITH SPECIAL REGARD TO THE AREA OF MILITARY ELECTRONICS}

\author{
GÁL Bence; NÉMETH András \\ (ORCID: 0000-0002-4663-6392); (ORCID: 0000-0003-2397-189X) \\ bence.gal.94@gmail.com; nemeth.andras@uni-nke.hu
}

\begin{abstract}
Absztrakt
Az innovatív, forradalmi technológiaként számon tartott $3 D$ nyomtatás lehetöségek széles skáláját biztositja a haderők számára. $A$ tanulmány célja, hogy tudományos módszerekkel vizsgálva a szakterület sajátosságait, komplex képet nyújtson a különböző additív gyártási módszerek funkciójáról, a felhasználható alapanyagokról, rávilágítva a hadiipari és haditechnikai alkalmazások széles spektrumára, melyek könnyen lehet, hogy a jövőben alapjaiban változtatják majd meg korunk hadviselésének technikai támogatását.
\end{abstract}

Kulcsszavak: additív gyártás, 3D nyomtatás, katonai alkalmazás, katonai elektronika

\begin{abstract}
Innovative, revolutionary $3 D$ printing technology provides an extensive range of military solutions. The primary objective of the present study is to provide a comprehensive overview of the functions of various additive manufacturing technologies, its unique assets, and raw materials, highlighting the wide range of applications in defence industry and military technology, which may easily and fundamentally change the technological support to modern warfare.
\end{abstract}

Keywords: additive manufacturing, $3 D$ printing, military applications, military electronics 


\section{BEVEZETÉS}

Sokan új ipari forradalomként, mások egy egész korszakot meghatározó technológiaként tartják számon az additív gyártástechnológiákat. A 3D nyomtatással kapcsolatos cikkek, leírások, publikációk, felhasználható modellek száma a világhálón az elmúlt években figyelemre méltó emelkedést mutat.

Tekintettel arra, hogy a technológiai fejlesztések súlypontja az utóbbi időben a védelmi szféra irányából eltolódott a polgári alkalmazások felé, az ezzel kapcsolatos dokumentációk jelentős része egyszerüen hozzáférhetővé vált, így a korábbi tendenciáknál is gyorsabb fejlődést diagnosztizálhatunk, illetve prognosztizálhatunk. Mivel azonban a hadiipar továbbra is a fejlett, technológiák egyik, ha nem a legnagyobb befogadója és integrálója, érdemes megvizsgálni, hogy a technológia széles körü elterjedése milyen hatással lehet az ágazat jövőjére nézve.

Az alábbi tanulmányban a szerzők egy rövid betekintést nyújtanak különböző additív gyártási folyamatokba, valamint azon alkalmazási alternatívákba, melyet a 3D nyomtatás a haditechnika számára kínál, megvizsgálva olyan katonai eszközök additív gyártásának lehetőségét és metódusát, mint a lőfegyverek, vagy a pilóta nélküli repülőeszközök. Tárgyalásra kerül a technológia jelentősége a modern, elektronizált hadseregek szemszögéből olyan, ma már additív módszerekkel is „megközelíthető” területek bemutatásával, mint a szenzor- és antennatechnika, valamint az IoT ${ }^{1}$.

\section{ADDITÍV GYÁRTÁS}

Az additív gyártás $\left(\mathrm{AM}^{2}\right)$ olyan technológiai megoldások összessége, melyek háromdimenziós formákat hoznak létre azáltal, hogy vékony rétegeket visznek fel egymásra. Az additív gyártástechnológiák tehát nem igényelnek előgyártmányt, lényegében a „semmiből” felépítve készítik el az adott tárgyat. [1]

A folyamat (1. ábra) egy digitális, háromdimenziós modell számítógépes tervezőprogrammal $\left(\mathrm{CAD}^{3}\right.$ szoftverek) történő megalkotásával, vagy egy valós tárgy háromdimenziós szkennelésével kezdődik. Nyomathatóság szempontjából mindkét folyamat egyik fó célja egy szilárdtest objektum létrehozása, melyhez ez utóbbi esetben sokszor számos utómunkára is szükség lehet. Ezt követöen megtörténik a 3D modell szeletelése, azaz vékony rétegekre bontása, illetve a nyomtató számára „olvasható” olyan vezérlő fájl előállítása, amely lépésenként tartalmazza az eszköz müködtetéséhez szükséges minden paramétert ( $\mathrm{pl}$. koordináták, sebességek, időzítések). A nyomtatási folyamatot a fájl feltöltésével és futtatásával tudjuk elindítani. A 3D nyomtató feldolgozza az abban kódolt utasításokat, és fokozatosan egymásra építi az egyes rétegeket a rendelkezésre álló alapanyagból, egészen addig, amíg ki nem alakul a gyártmány végleges formája. A 3D nyomtatóknak müködési elv alapján számos gyakorlati implementációja létezik, de osztályozhatjuk azokat például fizikai méret (hasznos munkaterület nagysága), forma, a felhasználható anyagok típusa, a nyomtatófejek száma, vagy egyéb szempontok szerint is.

\footnotetext{
${ }^{1}$ Internet of Things

${ }^{2}$ Additive manufacturing

${ }^{3}$ Computer-Aided Design
} 

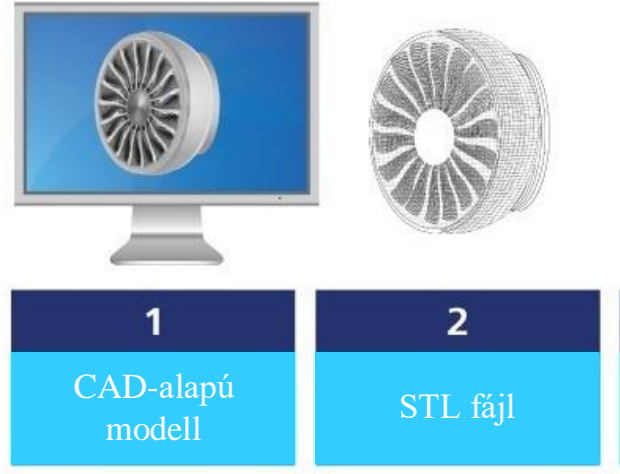
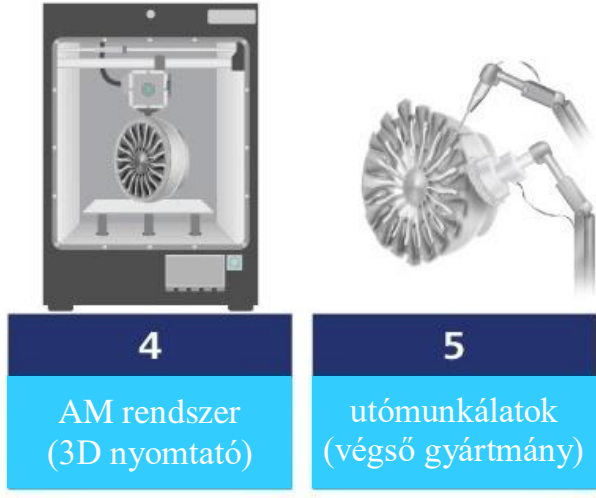

1. ábra. A 3D nyomtatás folyamatának lépései [2]

\section{Additív gyártástechnológiák}

Scott Crump, a Stratasys Inc. társalapítója által 1989-ben szabadalmaztatott műanyag szálolvasztásos $\left(\mathrm{FDM}^{4}\right)$ módszer az egyik leggyakrabban használt additív gyártási eljárás, köszönhetően annak, hogy jelenleg ez biztosítja a legköltséghatékonyabb termék-elöállítás lehetőségét. Az FDM eljárást használó gépek közös ismérve, hogy az alapanyag (mely minden esetben valamilyen hőre megolvadó müanyag, termoplasztik) milliméteres átmérőjű szál (filament) formájában, feltekercselve áll rendelkezésre. Ezt a szálat egy léptetőmotor húzza be a felmelegített nyomtatófejbe, ahol megtörténik annak megolvasztása ( $\mathrm{ABS}^{5}$ müanyag szál alkalmazása esetében körülbelül 230 Celsius fokon), majd az így keletkezett olvadék kipréselése a néhány tized milliméter átmérőjü fúvókán keresztül. Ez a megolvasztott műanyag nem sokkal azt követően, hogy kijutott a fejből lehűl, miközben a rétegek egymáshoz tapadnak. [3] Egy tipikus FDM rendszerben az extrudáló fej vízszintesen mozog a munkaasztal fölött, azzal párhuzamos síkban, miközben az egyes rétegek felvielét követően a munkaasztal lépésenként süllyedve távolodik tőle. Mint ahogyan az a későbbiekben bemutatásra kerül, többek között moduláris szerkezetü pilóta nélküli repülőeszközök szerkezeti elemei is könnyedén és gyorsan gyárthatók a technológia segítségével, amely kis darabszámok előállítsa esetén lényeges költségcsökkentő tényezőt jelent.

Az sztereolitográfia $\left(\mathrm{SLA}^{6}\right)$ lényege, hogy a rendszer folyékony halmazállapotú - bizonyos hullámhosszúságú fény hatására megszilárduló - mủanyagokból (ún. fotopolimerek) készíti el a megtervezett háromdimenziós tárgyat. Charls Hull, a 3D Systems társalapítója szabadalmaztatta az első, gyakorlatban is megvalósított gyors prototípusgyártási eljárásként 1986-ban. Az SLA folyamat során a gyártmány egy olyan munkaasztalon jön létre, amit egy rétegnyivel a fotopolimerrel teli kád felszíne alá pozícionálnak. Az UV fény a CAD modell kétdimenziós szeleteinek megfelelően végigpásztázza a folyadék felszínét egészen addig, amíg a fotopolimer a kívánt területeken el nem éri szilárd halmazállapotát. Ezt követően az egész platform az adott rétegvastagságnak megfelelően mélyebbre merül a kádban, melynek eredményeképpen a már megszilárdult rétegre ismét folyékony fotopolimer kerül. A gyártás során ez a metódus ismétlődik egészen addig, amíg az eszköz el nem éri végleges formáját. (Inverz eljárás esetén a levilágítás, azaz az egyes rétegek megszilárdítása a kád alján történik és a munkadarab fokozatosan kerül kiemelésre fotopolimerből.) Az alkatrész geometriájától

\footnotetext{
${ }^{4}$ Fused Deposition Modelling

5 Acrylonitrile Butadiene Styrene

${ }^{6}$ Stereolithography Apparatus
} 
függően a folyadékréteg optimális kialakításához különböző mechanikai támasztékok alkalmazása is szükséges lehet, melyek a gyártás után egyszerüen eltávolíthatók. Az elkészült gyártmányokat gyakran UV fény segítségével utólag még le is kell világítani, hogy végleges szilárdságukat elérjék. [5] Hadiipari fejlesztések során elsősorban olyan folyamatokhoz célszerü alkalmazni, ahol a pontosság a legfontosabb alapkövetelmény (például prototípusgyártás), figyelembe véve azt a tényt, hogy egy-egy tárgy nyomtatása jóval hosszabb időt vesz igénybe, mint egy FDM nyomtató esetében. A másik, szintén fotopolimerizáció elvén müködő gyártástechnológia, a folyékony fotopolimer projektor fénye által történő levilágítása $\left(D^{7}{ }^{7}\right)$. DLP nyomtatókkal az esetek többségében nagyobb nyomtatási sebesség érhető el, mint SLA esetén, tekintettel arra, hogy a projektor segítségével a réteg egészét egyszerre világíthatjuk le. Ugyanakkor a fentiekből adódik, hogy az elérhető maximális felbontást a projektor felbontása határozza meg, azaz általában korlátozza, ami például egy „full HD” projektor esetében 1080p. [6]

A szelektív lézeres szinterezés $\left(\mathrm{SLS}^{8}\right)$ technológiát az 1980-as évek legvégén fejlesztette ki Carl Deckard, majd 2001-ben a 3D Systems vásárolta fel azt. Ez az eljárás a korábban említettektől eltérően már finomszemcséjü por állagú alapanyaggal dolgozik. Müködésének lényege, hogy a 3D nyomtató munkafelületén a berendezés a kívánt rétegvastagságban eltéríti az alapanyagot, majd a felette elhelyezkedő lézer, a CAD modell adott rétege geometriájának megfelelően mozgó tükörrendszer segítségével végigpásztázza azt. A levilágított por szintereződik ${ }^{9}$, azaz a szomszédos részecskékkel összekapcsolódva megszilárdul, aminek következtében kialakul a kívánt forma. A platform ezek után tovább ereszkedik, és újabb porréteg kerül terítésre. [7] Katonai alkalmazások területén, tekintettel arra, hogy a technológiával jó mechanikai tulajdonságokkal rendelkező eszközök készíthetők, egyes fegyveralkatrészek additív gyártása is kézenfekvő lehet, de a robotika, mint potenciális felhasználási terület kerülhet előtérbe a jövőben.

Az SLS eljáráshoz hasonlóan, a porágyfúzió elvén müködő additív gyártási technológia a szelektív lézeres megolvasztás $\left(\mathrm{SLM}^{10}\right)$, és az elektronsugaras megolvasztás $\left(\mathrm{EBM}^{11}\right)$. A különbség az SLM és az EBM között mindösszesen annyi, hogy míg az elöbbi egy nagy energiájú lézersugarat használ fel a fémpor megolvasztáshoz, addig az utóbbi nagy energiájú elektronsugárral éri el ugyanezt a hatást. [8] Ezekkel az eljárásokkal szinte bármilyen fémporból teljesértékü, nagypontosságú gyártmányok állíthatók elö, így akár a harc- és gépjárművek, munkagépek, vagy repülőeszközök fémalkatrészei is rövid időn belül reprodukálhatók akár tábori körülmények között is, ezáltal jelentősen lerövidíthető az alkatrészutánpótlás, és javítás folyamata.

\footnotetext{
${ }^{7}$ Digital Light Processing

${ }^{8}$ Selective Laser Sintering

${ }^{9}$ Szinterezés: ennél az eljárásnál nem történik meg a porszemcsék teljes megolvasztása, csupán addig melegítik, illetve hevítik azokat, amíg közöttük molekuláris szinten a kémiai kötés létre nem jön.

${ }^{10}$ Selective Laser Melting

${ }^{11}$ Electron Beam Melting
} 

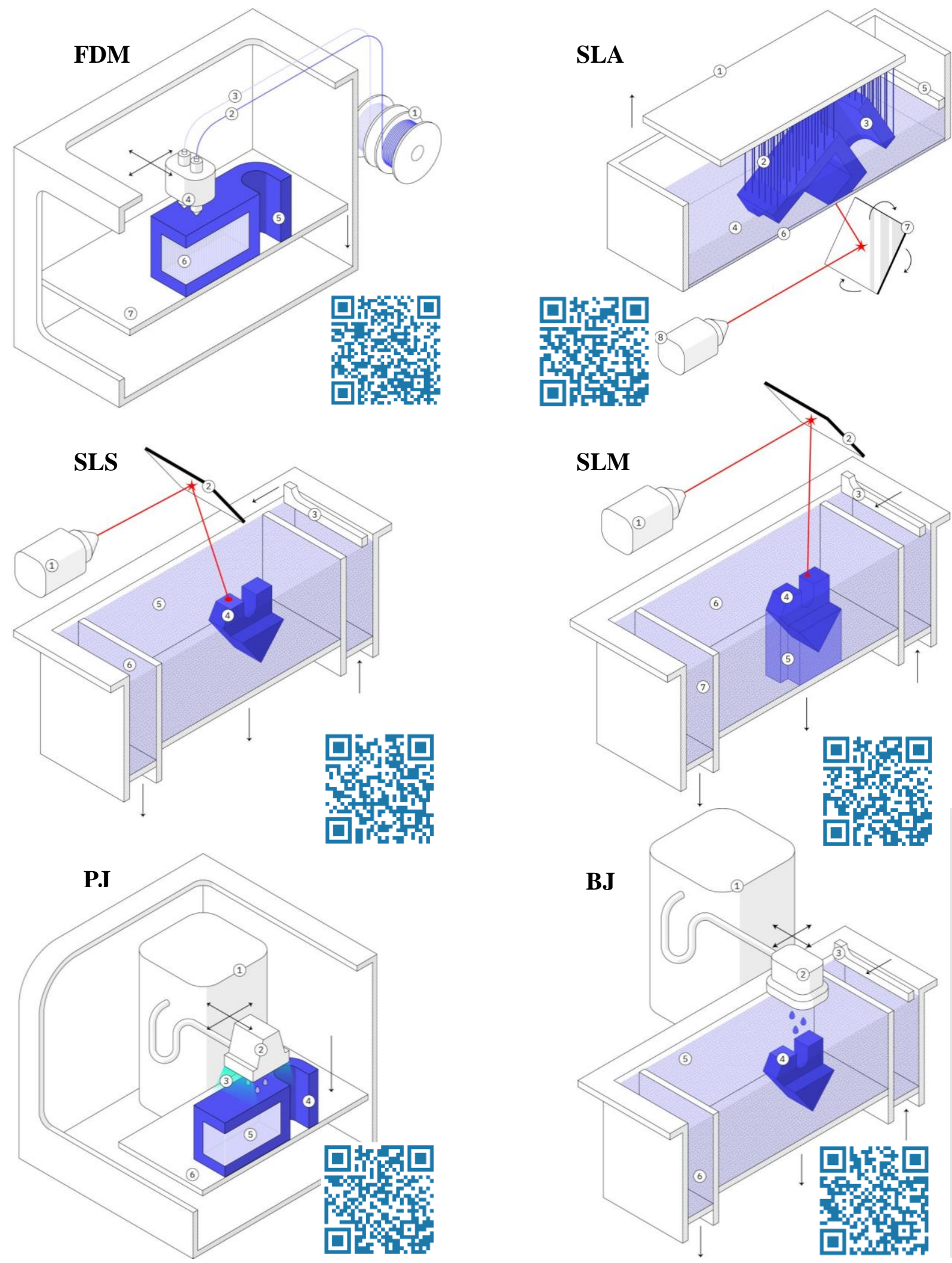

2. ábra. A 3D nyomtatási eljárások (FDM, SLA, SLS, SLM, PJ, BJ) [9]

Az úgynevezett ,jettingelő" 3D nyomtatási eljárások közül a fotopolimer jetting (PJ) technológia (PolyJet) során a munkaasztalra folyékony fotopolimert csepegtetünk, melyet UV 
fény segítségével, közvetlenül a munkaasztalra kerülést követően szilárdítunk meg, míg a binder $^{12}$ jetting $(\mathrm{BJ})$ módszer esetén egy nyomtatófejen keresztül kipréselt speciális kötőanyagot használunk a por állagú alapanyag összetapasztásához. [9] Mind a fotopolimer, mind a kötőanyag jetting eljárások igen pontos additív gyártási technológiák, melyek kellően sima felületet, jó kidolgozottságot, elegendően hosszú élettartamot biztosítanak akár haditechnikai célú eszközök, alkatrészek, kiegészítők gyártásához is.

A laminálás elvén történő gyártás $\left(\mathrm{LOM}^{13}\right)$ során az eszköz egyik fontos eleme egy olyan léptetőszerkezet, görgő (2), amely a lapanyagok, lemezanyagok továbbításáért felelös. A munkaasztalon lézerfény alkalmazásával történik meg a metszetek külső és belső kontúrjának vágása (4), majd a felmelegített henger (3) segítségével az összeragasztási folyamat. A platform (1) ezután egy rétegnyivel mélyebbre süllyed, és a munkadarab fölé újabb réteg kerül (3. ábra). [10] A jettingelő és lamináló eljárások már lehetővé teszik színezett objektumok kialakítását, így segítségükkel többek között 3D domborzati modellek, terepasztal szelvények is előállíthatók, melyeket fel lehet használni például harcászati, vagy hadmüveleti tervezés, vagy a csapatvezetés során.

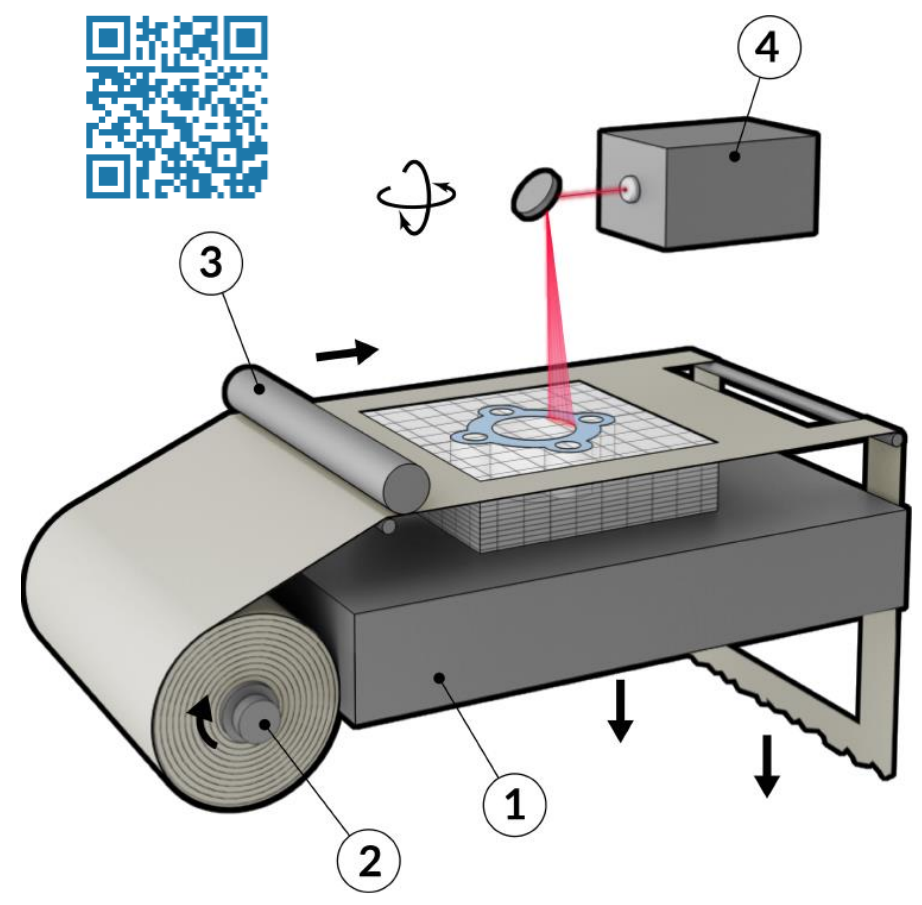

3. ábra. A 3D nyomtatási eljárások (LOM) [11]

\section{KATONAI ALKALMAZÁSOK}

A 3D nyomtatás katonai alkalmazása jelenleg még a világ legtöbb országban kezdetleges stádiumban van, de sok helyen használják már a haditechnikai eszközök fejlesztése során elsősorban prototípusgyártási célzattal, vagy ritkábban késztermékek előállítására. Ugyanakkor a technológia alkalmazása különböző alkatrészek, kiegészítők előállítására és az elhasználódott elemek reprodukciójára, cseréjére jelentősen felgyorsíthatja a termelési, utánpótlási és javítási

${ }^{12}$ A ,binder” szó magyar fordításban kötőanyagot, ragasztót jelent.
${ }^{13}$ Laminated Object Manufacturing 
folyamatokat, minimálisra csökkentve az igény felmerülése és a késztermék legyártása között eltelt időt. Az eljárás implementálása stacioner és tábori körülmények között magában hordozhatja a logisztikai folyamatok így az ellátási lánc egyszerüsödését is, mivel a 3D nyomtatók alkalmazása lehetőséget biztosít a szükséges eszközök helyben történő előállítására is.

\section{Additív gyártmányok jellemzői}

Katonai alkalmazások esetén az adott feladathoz megfelelő eljárás kiválasztása során számos tényezőt figyelembe kell venni, mint az eszközök beszerzési, üzemeltetési és karbantartási költségeit és körülményeit (pl. energiaellátás, helyigény), várható életciklusát, fizikai korlátait (pl. a munkaterükben létrehozható objektumok minimális és maximális méretei, illetve pontossága, fajlagos gyártási sebesség), valamint a nyomtatási folyamatot követő utómunkálatokhoz szükséges idő és szaktudás mértékét. Az alkatrészutánpótlás biztosítása szempontjából célszerü figyelembe venni, hogy ma már a 3D nyomtatók mechanikájának elemei, mozgó- és egyéb kopóalakatrészek jelentős része szintén előállítható valamely additív eljárással, ami csökkentheti a javítási ciklusok időigényét, ezáltal javítva a katonai alkalmazás feltételrendszerét. Másik fontos szempontcsoport a felhasználható alapanyagokhoz kötődik, így az alkalmazhatóságot befolyásolja többek között azok fajtája, mechanikai és egyéb tulajdonságai, rendelkezésre állása, beszerzési költségei.

A korábban bemutatott eljárások tekintetében az alábbi jellemzőket célszerü figyelembe venni. Az FDM jelenleg a leggyorsabb és legolcsóbb megoldás prototípusgyártás és alacsony szériaszámú gyártás esetén. Hőre lágyuló müanyagokat (pl. $\mathrm{PLA}^{14}, \mathrm{ABS}^{15}, \mathrm{PE}^{16}, \mathrm{TPU}^{17}$, $\mathrm{ASA}^{18}, \quad \mathrm{PEI}^{19}, \mathrm{PETG}^{20}, \mathrm{HIPS}^{21}$ ) használ, amelyek erősen korlátozott mechanikai tulajdonságokkal és környezeti ellenállóképességgel rendelkeznek. A filamentgyártók bizonyos paraméterek javítása érdekében (pl. szilárdság, rugalmasság, hőállóság, vezetőképesség) különböző adalékanyagokat (pl. fémszemcsék, szén-nanocsövek, gipsz, fa) alkalmaznak. Az ilyen eljárással készült tárgyak látható réteghatárokkal, anizotrop mechanikai tulajdonságokkal rendelkeznek, dimenzionális pontosságuk korlátozott, és a gyártás során bizonyos alapanyagok esetén számolni lehet a hirtelen hőmérsékletváltozás, vagy térben és időben nem egyenletes hülési folyamatok hatására bekövetkező deformációval. [11] Ez utóbbinak káros következményei (pl. szélek felhajlása) fütött munkaasztal, illetve zárt nyomtatási tér használatával csökkenthető. Olyan geometriák esetén, ahol a nyomtatás során kihúzott szálnak

\footnotetext{
${ }^{14}$ Polylactic acid - politejsav (olcsó, biológiai úton lebomló, hőre lágyuló műanyag, melyet általában magas keményítőtartalmú gabonafélékből állítanak elö, ideális nem funkcionális prototípusokhoz)

${ }^{15}$ Akrilnitril-butadién-sztirol (a PLA-nal jobb mechanikai és termikus tulajdonságokkal rendelkező, ütés-, hő- és vegyszerálló, nagy keménységü és szilárdságú hőre lágyuló műanyag)

16 Polietilén - nylon (kiváló mechanikai tulajdonságokkal, nagy kémiai- és kopásállósággal rendelkező hőre lágyuló műanyag, alkalmazható funkcionális modellek létrehozására is)

17 Thermoplastic polyurethane (alacsony keménységű, ütés és törésálló, rugalmas, könnyen hajlítható és tömöríthatő hőre lágyuló műanyag)

${ }^{18}$ Akrilnitril-sztirol-akrilát (erős, merev, vegyszer-, UV és időjárásálló hőre lágyuló műanyag, kevésbé torzul, mint az ABS, kültéri alkalmazásokhoz optimális)

19 Poliéterimid (hőálló, szilárd, közepesen ütésálló, jó mérettartással, kémiai és UV ellenállóképességgel rendelkező hőre lágyuló műanyag)

${ }^{20}$ Polietilén-tereftalát(-glikol) (erős, a PLA-nal rugalmasabb, ütésálló, alaktartó, újrahasznosítható, szagtalan hőre lágyuló mủanyag)

${ }^{21}$ Ütésálló polisztirol
} 
nagyobb távolságot kell áthidalni, vagy egy határoló fal dőlésszöge azt megköveteli, a deformáció elkerülése érdekében támasztékot kell alkalmazni, ami lehet valamilyen vízben, vagy más folyadékban oldódó támaszanyag (két nyomtatófej szükséges), vagy saját anyagából kialakított tartószerkezet (egyetlen nyomtatófej elegendö), melyet a nyomtatást követően mechanikus módszerrel el kell távolítani, és az így keletkező felületi egyenetlenségeket eldolgozni. Az ABS-ből készült tárgyak felülete acetongőzös utókezeléssel simítható, amely fényes felületet eredményez.

Az SLA és DLP nyomtatók esetében hőálló mügyanta alapú anyagokkal dolgozhatunk, amelyek nagypontosságú (akár 25 mikron), részletgazdag eszközök, sima felületek létrehozására alkalmasak. Alapesetben viszonylag törékeny, és kevéssé környezetálló (pl. napsugárzás) modellek kialakítása lehetséges, de egyes tulajdonságaikat különböző típusú adalékokkal tudják befolyásolni, javítani. Az esetek jelentős részében az elkészült gyártmányok jelentős utókezelést (UV levilágítás, támasztékok eltávolítása) igényelnek, ami tovább lassítja a gyártási folyamatot. Az alapanyagok fajlagos beszerzési költsége egy nagyságrenddel nagyobb, mint nyomtatószálak esetében, valamint a nyomtatás folyamata sokkal időigényesebb (DLP esetén gyorsabb), míg a létrehozható tárgyak nagysága lényegesen kisebb, mint FDM esetén, ezért csak speciális esetekben lehet indokolt alkalmazásuk. [11] Elsősorban koncepciós modellek, funkcionális prototípusok, makettek, rögzítőszerkezetek, öntőformák, mesterpéldányok, fogászati és egyéb orvosi modellek (pl. fúrósablonok) nyomtatására használják.

SLS technológia esetén elsősorban különböző megerősített szerkezetű műanyagokkal dolgozhatunk, melyek a szinterezés következtében jó, közel izotrop mechanikai tulajdonságokkal rendelkeznek. Nagypontosságú (100 mikronos) gyártást tesz lehetővé, és mivel a korábbi megoldásokkal ellentétben nem igényel alátámasztást (a porágy tölti be ezt a funkciót), olyan komplex geometriák hozhatók létre segítségével, amelyek akár utólagos összeszerelés, beavatkozás nélkül is tartalmazhatnak mozgó alkatrészelet. A munkatér teljes térfogata kihasználható a hatékonyság növelése érdekében, így egyszerre akár több tucat alkatrész is készíthető egyetlen gyártási fázisban ezzel az eljárással. A gyártmányok belső szerkezete nyomtatást követően bizonyos mértékig porózus, míg felülete szemcsés lesz, amelyen utókezeléssel lehet javítani. [11] A megoldás legnagyobb hátránya jelenleg a magas beszerzési és üzemeltetési költségekben rejlik, ám pozitív tulajdonságai miatt ideálisan használható kisszériás funkcionális alkatrészek és prototípusok előállítására. Közvetlen fém lézer szinterezéssel (DMLS ${ }^{22}$ ) már fémből készült alkatrészeket is előállíthatunk.

A szinterezéssel szemben, ahol a szemcséket csak addig melegítik, amíg molekuláris szinten össze nem kapcsolódnak, az SLM és EBM eljárások esetén az alapanyag megolvasztásra is kerül, így a hagyományos eljárásokkal készült gyártmányokéhoz hasonló, vagy azokat fölülmúló tulajdonságú, komplex geometriájú fém (acél, alumínium, titán, kobalt-króm, nikkelötvözetek) alkatrészeket tudunk elöállítani, reprodukálni. A legtöbb esetben a deformáció elkerülése érdekében merevítő, illetve tartószerkezettel együtt lehet csak ilyen tárgyakat nyomtatni, így a végtermék elkészítéséhez még komoly utómunkálatokat kell végezni. Ezek jelenleg a legköltségesebb eljárások, ahol az egy alkatrészre eső költség több ezer, vagy akár tízezer dolláros nagyságrendü is lehet, ezért olyan gyártmányok esetén célszerü csak alkalmazni, amelyek hagyományos fémmegmunkálási technikákkal nem kivitelezhetők, vagy

\footnotetext{
${ }^{22}$ Direct Metal Laser Sintering
} 
egy alkatrész cseréjének beszerzési nehézségek miatti elhúzódása lényegesen nagyobb veszteséggel járna. [11]

Akár fémből, vagy homokból készült eszközök alacsony költségü gyártására is lehet alkalmazni a BJ eljárást, ahol az anyag ömlesztése helyett ragasztóanyaggal kapcsolják össze a részecskéket. Természetesen ezáltal az anyag eredeti mechanikai tulajdonságai nem érvényesülnek olyan mértékben, mint ömlesztés esetén, de a tárgy színe meg fog egyezni az eredeti anyagéval, ami koncepcionális modellek, prototípusok esetén például elegendő lehet. Bár ezzel az eljárással is lehetőség van komplex formák kialakítására, komoly tervezési korlátozással kell számolni, mert ilyen eljárással finom részletek nem reprodukálhatók. [11] A ragasztóanyag színezésével lehetőség van színes modellek létrehozására is.

A PJ és LOM eljárások legfőbb előnye, hogy segítségükkel színes modellek is nyomtathatók költséghatékonyan a szükséges utómunkálatok minimalizálása mellett.

\section{Általános katonai alkalmazások}

Lőfegyver additív gyártására az utóbbi években több eredményes kísérletet is láthattunk, elsősorban műanyag szálolvasztásos és szelektív lézeres szinterezős megoldások alkalmazásával (1. kép). Az FDM technológiával nyomtatott lőfegyverek hátránya a rövid élettartam, hiszen a termoplasztikok hőfejlődés hatására megolvadnak, deformálódnak. [12] Tekintettel arra, hogy a fémnyomtatás költsége, ezzel együtt a különböző eljárásokat megvalósító nyomtatók ára jelenleg igen magas, a hibrid technológiával készülö lőfegyverek (Shuty MP-1) nyomtatása tünhet célszerünek, melyben a fém fegyverkomponensek (fémcső, ütőszeg, csavarok) müanyag komponensekkel vegyesen kerülnek felhasználásra.

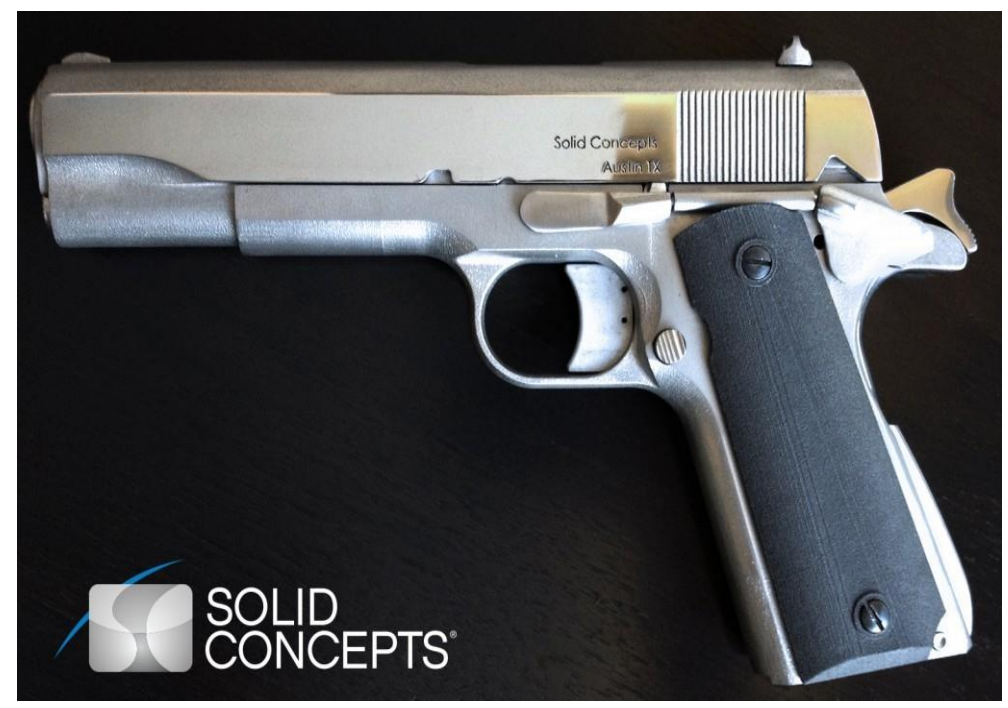

1. kép. Fémek közvetlen lézeres szinterezésével (DMLS) gyártott Reason [13]

Érdemes megjegyezni, hogy az Amerikai Egyesült Államok (USA) hadseregének egyik kutatás-fejlesztéssel foglalkozó központja az ARDEC ${ }^{23}$ sikeresen tesztelt egy szelektív lézeres szinterezés eljárással készült gránátvetőt, amely arra enged következtetni, hogy az USA komolyan gondolja az additív gyártástechnológiák hadiipari alkalmazását. [14]

${ }^{23}$ US Army Armanent Research, Development and Engineering Center 
A fentiek alapján megállapítható, hogy katonai alkalmazású lőfegyverek tömeges nyomtatásához még jelentős technológiai fejlődésre lenne szükség, ugyanakkor az additív gyártástechnológiák eredményesen alkalmazhatók fegyverzeti szakanyagok prototípus tervezése során, fegyver-kiegészítők gyártására, valamint konstrukciós vizsgálatokhoz szükséges eszközök legyártására egyaránt.

A 3D nyomtatás orvostudományi alkalmazásai igen széleskörüek, így protézisek, implantátumok, orvosi modellek, csontpótlások egyaránt elkészíthetők megfelelő additív gyártóberendezéssel (2. kép). A 3D nyomtatás egyik különleges és gyorsan fejlődő orvostechnológiai ágazata a bionyomtatás, amely szövetek, szervek additív gyártásának lehetőségét kutatja. Érdemes figyelmet szentelni ugyanakkor a gyógyszerek készítésére is, hiszen ilyen eljárások segítségével személyre szabott, optimalizált hatóanyagú tabletták készítése is megvalósítható, ezáltal növelve az előállított gyógyszerek hatékonyságát, minimálisra csökkentve azok mellékhatásait. [15]

A fentiek alapján könnyen belátható, hogy a katonai orvoslás területén is számos lehetőség kínálkozik a technológia alkalmazására. 3D nyomtatók segítségével gyorsan kivitelezhetők a számítógépes szoftverekkel tervezett implantátumok, pótolhatók az égés következtében elhalt bőrszövetek, illetve beállíthatók a gyógyszerek hatóanyagai az egyén szükségletei alapján. Ezen megoldások alapjaiban könnyíthetik meg az egészségügyi ellátást mind hazai, mind pedig müveleti területen történő feladatvégrehajtás esetén, gyors és hatékony segítséget nyújtva a sérült, beteg katonák ellátásához, kezeléséhez.

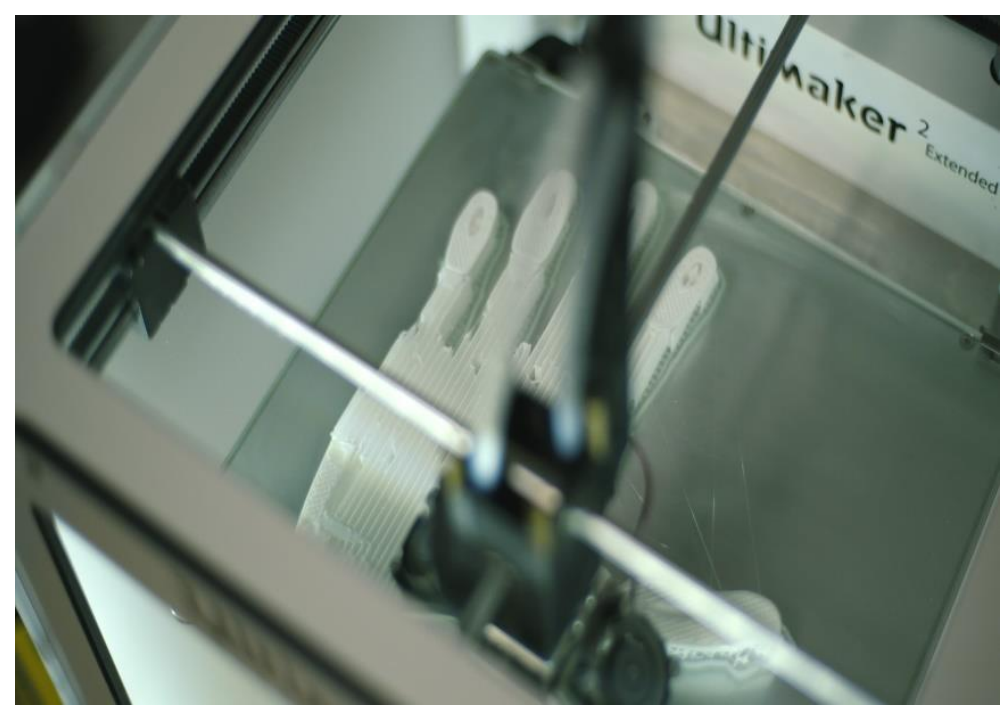

2. kép. Kézfej protézis nyomtatása [16]

Az additív gyártástechnológiák előnyeit - így a bonyolult, komplex geometriák minimális anyagveszteséggel történő elöállításának lehetőségét, nagyfokú tervezési szabadság biztosítását és a költséghatékony gyártási folyamatot - maximálisan kihasználó ágazat a robotika. A haditechnika ezen a területen szintén sokat profitálhat az additív gyártástechnológiák térhódításából, ugyanis a katonai robotok alkalmazási területei igen széleskörüek, így a rugalmasság és a gyors adaptáció képessége egyaránt fontos tényező ezen eszközök előállítása során. A 3D nyomtatási eljárással készült, akár speciális kialakítású robotok megfelelő elektronikával, szenzorokkal kiegészítve (melyek szintén additívan gyárthatók) és programkóddal feltöltve, képesek harcászati, vagy magasabb szintü katonai müveletek hatékony támogatására. 
A robottechnológia egy speciális, még kezdeti stádiumban lévő területe az úgynevezett „szoft robotika” (soft robotics), amely alapját a merev vázak és gépies mozdulatok helyett a természetben előforduló mozgások imitációja képezi. [17] A 3D nyomtatás térnyerése ezen terület fejlödésének is új lendületet adhat, hiszen a két területen használatos alapanyagok sok esetben kompatibilitást mutatnak. [18]

A 3D nyomtatott élelmiszer-készítés (3. kép) az additív gyártástechnológiák egy újabb olyan ágazata, melynek alkalmazása a jövőben akár alapjaiban változtathatja meg a katonák élelmezési ellátását is. A többnyire extrudálással, vagy szinterezős megoldással előállított, lényegében csak szerkezetükben különböző élelmiszerek készítésének egyik legnagyobb előnye a fehérjék, ásványi anyagok és vitaminok egyéni szükségletek alapján történő adagolása. [19] Az optimális összetétel meghatározásához segítséget nyújthatnak majd a katonák felszerelésébe integrált egészségügyi szenzorhálózat által szolgáltatott adatok, illetve az emberi szervezet pillanatnyi fiziológiai állapotát meghatározni képes gyors diagnosztikai eljárások.

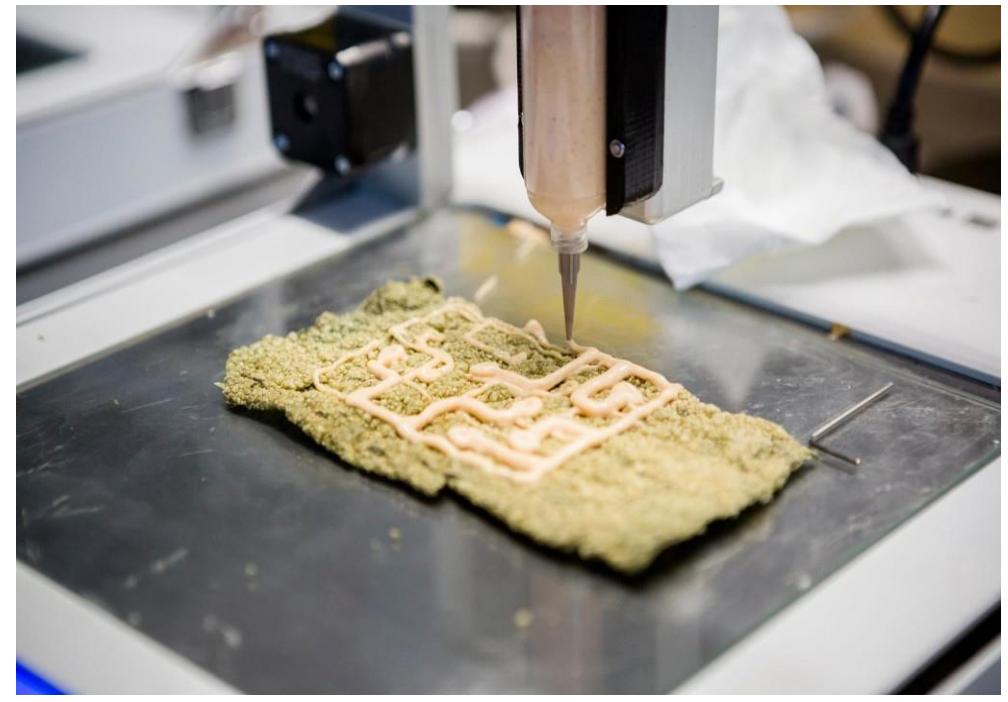

3. kép. A technológia fejlődésével elérhetővé válik élelmiszer nyomtatása is [20]

Érdemes megjegyezni továbbá, hogy számos, cipők fejlesztésével és forgalmazásával is foglalkozó vállalat (pl. Adidas, Nike, New Balance, Under Armour) az egyéni igényeket és a személyre-szabhatóságot szem előtt tartva készít ergonómiailag tökéletes 3D nyomtatott lábbeliket. [21] Ezt a megoldást és a jellemző tendenciákat szem előtt tartva megállapíthatjuk, hogy a technológia alkalmassá válhat arra, hogy a jövőben a katonák felszerelésének az egyénre szabott és az egészségügyi szenzorhálózat egyes elemivel felszerelt bakancsok is részévé váljanak.

Amennyiben megvizsgáljuk textil, illetve ruhanemük additív gyártásnak lehetőségét, megállapíthatjuk, hogy például olyan rugalmas műanyagok alkalmazásával, mint a TPU, nyomtatott szövetek is elöállíthatók lesznek. [22] A fenti gondolatmenethez kapcsolódva feltételezhetjük, hogy az integrált szenzorhálózatot is magába foglaló nyomtatott egyenruhák prototípusaira sem kell majd sokáig várnunk.

A következökben pár gondolat erejéig ismertetésre kerülnek olyan alkalmazások is, amelyek a fenti kategóriák egyikébe sem sorolhatók be ugyan, mégis érdekesek lehetnek a technológia jövőjét illetően. Oroszországban lézeres szinterezős technológiával fémporból előállított lőszereket teszteltek, melyek több szempontból is hasonlóan jó eredményeket értek el, mint a hagyományos módszerrel előállítottak. [23] Szintén Oroszországban az Electromashina nevü 
vállalat az Armata tank egyes alkatrészeinek prototípus gyártásához alkalmazza a technológiát, amely nagymértékben rövidíti a tesztelési folyamatokat, minimálisra csökkentve a tervezés és a késztermék legyártása között eltelt időt. [24] Elörehaladott kutatások folynak a 3D technikával nyomtatott mikro müholdak vonatkozásában, amely tökéletesen mutatja, hogy az additív gyártástechnológiák terjedése nagy áttörést jelenthet az ürszegmens felhasználása területén is, ami kezdetben a kisebb méretü müholdak gyártására korlátozódik ugyan, de felveti a haditechnikai alkalmazások lehetőségét ezen a speciális területen. [25] Már napjainkban is nagy hangsúlyt kap a 3D nyomtatás a repülőmüszaki fejlesztések vonatkozásában, ami elsősorban a repülöeszközök elavult, elöregedett müanyag komponenseinek kiváltását, illetve megerősítését hivatott célozni, de a repüléstechnikában gyakorta használatos titán nyomtatásának lehetőségével a paletta tovább bővülhet. [26]

\section{ALKALMAZÁSI LEHETŐSÉGEK A KATONAI ELEKTRONIKA TERÜLETÉN}

Az additív gyártástechnológiák felhasználhatók különböző elektronikai komponensek, ellenállások, kondenzátorok, induktivitások, félvezető alapú aktív alkatrészek és huzalok csaknem tetszőleges felületen történő kialakítására, ezáltal komplex áramkörök, vagy akár vezeték nélküli szenzorok különböző felszerelésekbe történő integrálására. [27] Az elektronikai alkatrészek paraméterei a felhasznált anyagok minőségi jellemzőivel, adalékanyagok alkalmazásával, és megfelelő geometriák kialakításával állíthatók be egészen pontosan. [28]

Az additív gyártástechnológiák sajátos jellemzőiből következik, hogy a különböző elektronikai komponensek, vezető szálak többféleképpen kerülhetnek beépítésre a nyomtatott szubsztrátba. Többrétegü elektronikus áramkörök készítésénél legkézenfekvőbb megoldás az egyes alkatrészek szubsztrátba történő integrálása, melynek egyik fontos előnye, hogy a nem kívánt környezeti hatásoktól ezen komponensek védve maradnak a hordozó sértetlenségéig. A technológia segítségével lehetőségünk van az alkatrészek egy, már létező háromdimenziós struktúrára való nyomatására is, kiváltva ezzel az $\mathrm{SMT}^{24}$ komponensek összeszerelő lépéseit. [29] A háromdimenziós elektronikus egységek (3D-MID ${ }^{25}$ ) területén folyó fejlesztések során a készülékházak előállítására is gyakran additív technológiákat (FDM, SLS) alkalmaznak, a költséghatékonyság érdekében. [30] A már korábban említett additív folyamatokon kívül a jobb rádiófrekvenciás tulajdonságok elérése érdekében előszeretettel alkalmazzák az Optomec által szabadalmaztatott, akár 10 mikronos nyomtatási pontosság elérésére is képes aeroszolos „,vezetőképes anyag sugárszórás” (aerosol jet) eljárást is. A folyamat során (4. ábra.) az elektromosan vezető festéket egy folyadék-porlasztó készülékbe helyezik, amelyből távozva 15 mikron átmérőjü cseppecskéket képez. Az így keletkező sürü, ködszerü anyag ezt követően a lerakófejbe kerül továbbításra. A pontos nyomtatást egy tiszta, száraz nitrogéngáz köpeny teszi lehetővé, melynek segítségével megtörténik a nyomtatófejben lévő, nagy sebességű aeroszol fókuszálása. [31]

Az imént felsorolt eljárások implementációja magában hordozza a lehetséges haditechnikai alkalmazások széles spektrumát, mivel azok nem csupán nyomtatott áramkörök készítésére, hanem ezen áramkörök már meglévő fizikai formába történő beágyazására is alkalmasak. Az additív gyártástechnológiák segítségével megvalósítható különböző komplex sugárzóeszközök előállítási folyamatának gyorsabbá és költséghatékonyabbá tétele, háttérbe szorítva a hagyományos mikromegmunkáló eljárásokkal készített antennákat. Mobileszközök gyártása során például az aeroszolos módszer alkalmazásával nanoméretű ezüstrészecskékből alakítják

\footnotetext{
${ }^{24}$ Surface Mount Technology

${ }^{25}$ Moulded Interconncet Devices
} 
ki az integrált antennákat (LTE ${ }^{26}, \mathrm{GPS}^{27}$, Bluetooth) (4. kép), ezáltal sima felületet, optimális kisugárzott antennateljesítményt elérve, így biztosítva a jóminőségü rádiófrekvenciás adatátvitel feltételeit. [32]

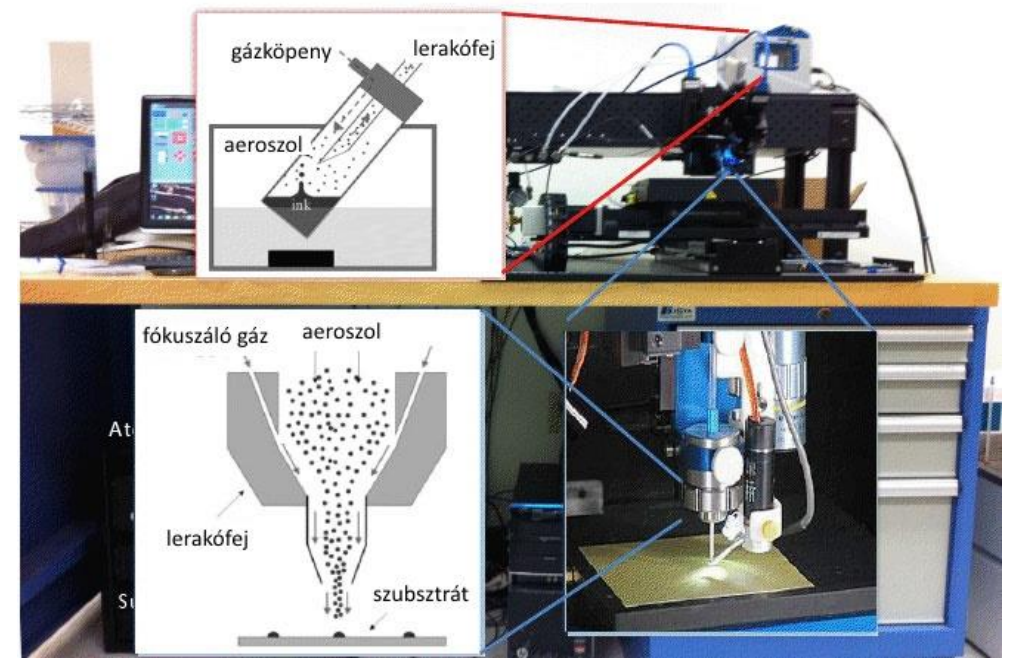

4. ábra. Az Aerosol Jet technológia müködési elve [33]

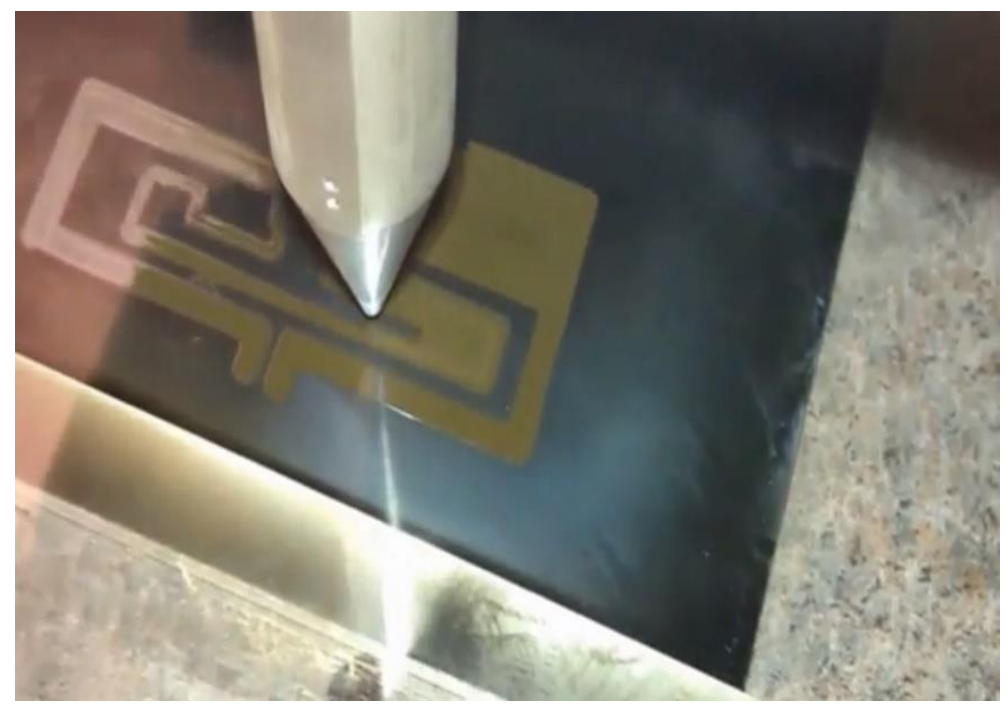

4. kép. Kétsávos antenna gyártása Aerosol Jet technológiával [32]

Az elmúlt évtizedek hadipari fejlesztéseit vizsgálva megállapítható, hogy az egyik fó cél az eszközök méretének folyamatos csökkentése a teljesítmény paraméterek javítása, de legalábbis szinten tartása mellett. A 3D nyomtatott antennakészítés teljes mértékben illeszkedik ebbe a technológiai trendbe, mivel az így gyártott eszközök a fizikai méretek jelentéktelen megváltozása mellett integrálhatók a különböző katonai felszerelésekbe (pl. sisakba), biztosítva a rádióhullámok kisugárzásának és vételének technikai feltételeit, lehetővé téve ezáltal a rádiókommunikációt, vagy éppen a pontos helymeghatározást.

A technológia az integrált antennakészítés mellett alkalmas továbbá mikrohullámon használatos nagyobb apertúrájú speciális antennák gyártására is. Az ilyen eszközök müködési

\footnotetext{
${ }^{26}$ Long Term Evolution - „hosszútávú fejlődés”, a 4. generációs vezeték nélküli adatátviteli szabvány
}

${ }^{27}$ Global Positioning System - globális (müholdas) helymeghatározó rendszer 
frekvencia alapján, egy CAD tervrajz segítségével is méretre szabhatók, de a tervezés történhet egy már meglévő, speciális iránykarakterisztikával rendelkező modell alapján is. Az antennajellemzőket többek között befolyásolja a nyomtatott felület egyenetlensége is, ami a felületi hatásfok romlásához, az iránykarakterisztika torzulásához vezethet. Az optimális nyomtatási eljárást kiválasztva, a megfelelő rétegszámú rézfesték egyenletes felvitelével maximalizálhatjuk a felület simaságát, ezáltal kedvező, akár a hagyományos gyártási eljárással készült sugárzóknak megfelelő antennajellemzőket elérve. [34] [35] A mikrohullámú antennáknak számos katonai alkalmazása ismert, így például müholdas kommunikációt és helymeghatározást segítő antennák, relék, mikrohullámú radarok, rádió felderítő- és zavaró berendezések antennái egyaránt készíthetők 3D nyomtatási technológia alkalmazásával.

A pilóta nélküli légijármüvek $\left(\mathrm{UAV}^{28}\right)$ használata az elmúlt évtizedben gyors fejlődésnek indult a katonai, közszolgálati, kereskedelmi és magáncélú alkalmazások tekintetében egyaránt. Az additív gyártási folyamatok kedvező tulajdonságai alkalmassá teszik a technológiát kisméretü komplex struktúrák rövid idő alatt történő megvalósítására, elkerülve a hagyományos gyártási metódusok munkaigényes folyamatait és az öntőformák alkalmazásának szükségességét. [36] Az elmúlt években több eredményes megoldás született pilóta nélküli repülőeszközök additív módon történő elöállítására, kiemelve ezek közül a Virginiai Egyetem által fejlesztett Razor UAV-t. Ezen eszköz legújabb prototípusa mindösszesen 9 komponensből áll, melyek egy ABS szálas FDM nyomtatóval egyszerüen előállíthatók és lényegében semmilyen egyéb eszközt nem igényelnek az összeszereléshez, mivel az alkatrészek könnyedén egymásba pattinthatók. Ami az elektronikát illeti, a drón „agyát” egy Android operációs rendszerü okostelefon képezi, amely egy egyedi tervezésű avionikai alkalmazást használ a repülő irányításához. A rendszer részét alkotja továbbá egy GPS, egy telemetria rádió, valamint egy robotpilóta, amely a mobiltelefontól kapott vezérlöjelek útján kapja meg az irányításhoz szükséges információkat. Az eszköz föbb paraméterei a következök: tömege $1 \mathrm{~kg}$ (elektronikával felszerelve 2,5 kg), maximális sebessége $60 \mathrm{~km} / \mathrm{h}$, repülési idö 45 perc. Az additív gyártási technológia egyik legnagyobb elönyével rögtön szembesülünk, hiszen az eszköz gyakorlatilag 24 óra leforgása alatt legyártható. [37]

Ahogyan a fentiekből kiderül, kisméretü, komplex struktúrák előállítására ideális megoldást kínálnak az additív gyártási eljárások, így a minibotok csapatban való együttmüködésére épülő, különböző feladatok kollektív intelligencián alapuló, önszerveződő megoldására is alkalmas mini-drónrajok 3D nyomtatása szintén potenciális felhasználási terület lehet. A feladatok végrehajtása során elveszett eszközök megfelelő tartalékképzéssel azonnal, reprodukció esetén pedig rövid időn belül (akár néhány óra) pótolhatók. A korábban említett eljárásokkal az antennák, illetve akár az áramkörök egy része is integrálható a géptörzsbe vagy szárnyba (5. kép), így az egyedek közötti kommunikáció is additív módon gyártott rádiófrekvenciás adóvevőkkel biztosítható. A rajban történő alkalmazás irányulhat kutató-mentő, megfigyelö, felderítő, ellenőrző, támadó és védelmi feladatok megosztott erőforrásokkal történő végrehajtására egyaránt.

A ,dolgok internete” (IoT) és a 3D nyomtatás kapcsolatát megvizsgálva kijelenthető, hogy a jövőben várhatóan komoly katonai aspektusokkal is számolni lehet. Az IoT olyan fizikai tárgyak hálózatát jelenti, melyek beágyazott technológiák, szenzorok segítségével állapotukat, vagy fizikai környezetüket érzékelik, valamint a hálózatra csatlakozott többi elemmel kölcsönös kapcsolatban vannak. [38] Az információs hadviselés korszakára a magas fokú elektronizáltság, és automatizáltság jellemző, amely biztosítja a katonai műveletek sikeres végrehajtásához szükséges információk gyors és megbízható áramlását a hálózat elemei között.

${ }^{28}$ Unmanned Aerial Vehicle 
Ennek megfelelően az IoT katonai megközelítése a müveletek során használt különböző információs rendszerekkel és az azokban használt eszközökkel hozható szoros összefüggésbe. A müveleti területen hálózatba kapcsolt, egymással egyre magasabb autonómia szinten kommunikáló eszközök és rendszerek biztosítják a katonák helyzetismeretét, valamint lehetőséget kínálnak különböző típusú adatok küldésére és fogadására egyaránt. Mivel az egyes elektronikai komponensek, áramkörök, vagy antennák additív gyártása különböző módszerekkel mára már elérhető, továbbá a közeli jövőben az ilyen módszerekkel az egyéni felszerelésbe integrált szenzorok és egyéb eszközök emberi beavatkozás nélkül fogják végezni feladatukat az arra kijelölt csatornán (gép-gép interfészeken) kommunikálva egymással, illetve a harcjármübe telepített átjátszóállomáson keresztül a vezetési pont központi döntéstámogató információs és harcvezetési rendszerével. Ez alapján, a katonákon kialakításra kerülő testhálózatok, illetve a hadszíntér minden más elemét is behálózó szenzorok rendszere tulajdonképpen egyfajta katonai IoT-ként aposztrofálható, melyek legtöbb elemét a jövőben várhatóan additív eljárásokkal, valamilyen 3D nyomtatási, vagy hibrid technológiával fogják majd a felszerelések különböző elemeibe integrálni. A fentiek alapján kijelenthető, hogy a 3DP technológia és az IoT közötti kapcsolat a jövőben egyre szorosabbá válhat, miközben a katonai alkalmazások arányának fokozódó ütemben történő növekedése prognosztizálható (5. ábra).

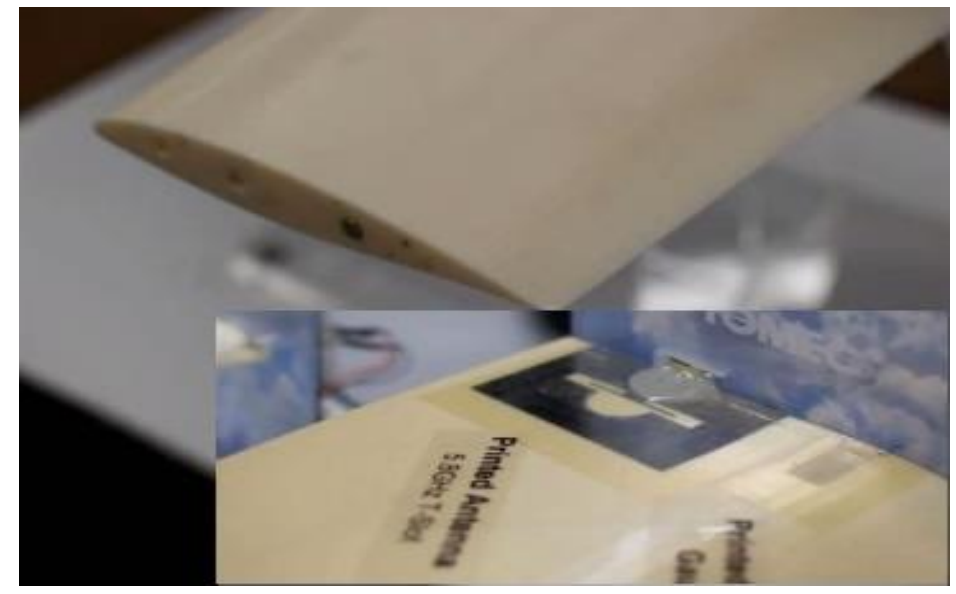

5. kép. FDM technológiával nyomtatott UAV szárny, Aerosol Jet eljárással felvitt antennával [39]

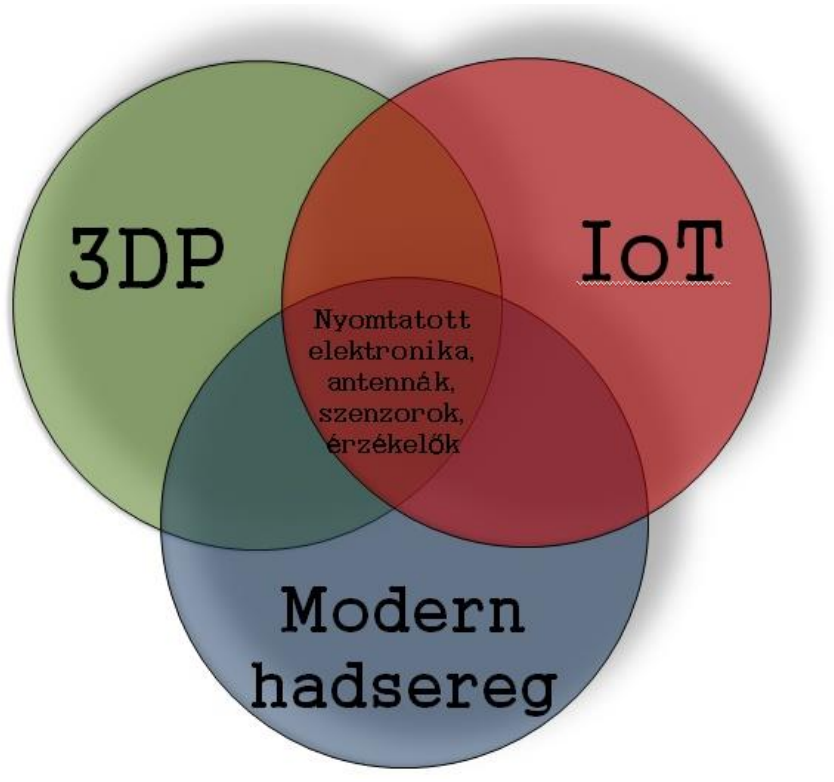

5. ábra. 3DP és az IoT katonai aspektusai (szerkesztették: a szerzők) 


\section{KÖVETKEZTETÉSEK}

Cikkünkben rövid áttekintést kívántunk nyújtani a különböző additív gyártási folyamatok müködéséröl, eszközrendszeréröl, a felhasználható alapanyagok köréről és jellemzőiröl, kiemelt figyelmet szentelve a katonai felhasználás egyes lehetőségeire, különös tekintettel a katonai elektronika területén azonosítható potenciális fejlődési irányokra. A kutatás során szerzett információk, tapasztalatok, vizsgálati eredmények értékelése és értelmezése alapján megállapítható, hogy a 3D nyomtatás területén az elmúlt években gyorsuló ütemben zajló fejlődési folyamatoknak köszönhetően letisztult módszerek és eljárások is állnak már rendelkezésre akár a professzionális ipari felhasználók, akár a kutatás, fejlesztés, innováció területén érdekelt cégek, illetve szakemberek számára egyaránt. A felhasználható alapanyagok köre folyamatosan bővül, miközben minőségük, és tulajdonságaik javulnak (esetenként adott felhasználáshoz optimalizálhatók). A gyártóplatformok pontosságának és más minőségi paraméterei javulásának, valamint a tervezési szabadságfok növekedésének is köszönhetően a lehetséges alkalmazások köre gyorsan szélesedik. Bár az egyes 3D technológiáknak vannak még korlátai, amelyek bizonyos mérnöki kompromisszumok árán már napjainkban is áthidalhatók, de a fejlődési tendenciák határozottan mutatnak abba az irányba, hogy a hagyományos gyártási eljárásokat bizonyos területeken fokozatosan háttérbe szorítják majd ezek az additív megoldások, miközben a termékfejlesztési folyamatok során, prototípusok elöállítása területén lassan egyeduralkodóvá válnak a legtöbb szakterületen.

A katonai eszközök kutatási és fejlesztési folyamatai során már széleskörben alkalmazzák ezeket a módszereket, miközben a fémnyomtatás magas költségeinek is köszönhetöen elsősorban a hibrid gyártási megoldásokat részesítik előnyben kisszériás eszközök, alkatrészek elöállítása esetén. A tömegtermelésben (nehéztechnika, fegyver, löszer, gépalkatrész) ugyanakkor sokat kell még várni a szubtraktív gyártási módszerek kiváltására, csak olyan alkatrészek esetén lehet célszerü az alkalmazásuk, amelyek más módszerekkel nem előállíthatók, vagy olyan esetben, amikor rövid időn belül van szükség egyes alkatrészek pótlására. Egyes speciális területeken, ahol közelebb járunk a költséghatékony megoldások implementálásához, mint például a katonai elektronika, vagy azon belül is a szenzortechnika, robotika, az infokommunikáció, az UAV-k, illetve akár a katonai orvoslás, gyógyászat és rehabilitáció területén ugyanakkor jelentős áttörés várható az alkalmazások tekintetében talán már közép, vagy rövidtávon is. A hálózatalapú hadviselés során alkalmazott „intelligens” eszközök és eljárások sok esetben már megkövetelik az 3D nyomtatásban rejlö lehetőségek maximális hatásfokkal történő kiaknázását, miközben a mesterséges intelligencia (MI) alkalmazásával lassan ezen a területen is egyre nagyobb mértékben számolni kell.

A technológia jövőjét kicsit tovább vizsgálva eljuthatunk a négydimenziós nyomtatás víziójáig, ami olyan eszközök előállításával foglalkozik majd, melyek képesek saját szerkezetük, fizikai tulajdonságaik megváltoztatására valamilyen környezeti hatásra, vagy annak megváltozására adandó válaszként. Ez a lehetőség teremtheti meg az alapját többek között a katonai álcázási technikák új dimenzióba történő lépésének. [40]

A fentiek alapján egyértelmüen körvonalazódni látszik, hogy a 3D nyomtatás komoly szerepet tölthet majd be a modernkori hadviselés eszközrendszerének technikai támogatásában. 


\section{FELHASZNÁLT IRODALOM}

[1] HUSI G.; SZEMES P.T.: Rapid prototyping technológiák-additív technikák, 2015. p. 41.; https://docplayer.hu/storage/39/18168546/1547323303/FTNMSPNiqkKAhZIIoz4ohA/1 8168546.pdf (letöltve: 2018.05.02.)

[2] https://dupress.deloitte.com/dup-us-en/focus/3d-opportunity/additive-manufacturing-3dopportunity-in-aerospace.html (letöltve: 2018.05.02.)

[3] 3D nyomtatás különböző technológiákkal I. - az FDM eljárás; https://3dnyomtato.wordpress.com/2013/07/12/3d-nyomtatas-kulonbozotechnologiakkal-i-az-fdm-eljaras/ (letöltve: 2018.05.03.)

[4] PALERMO, E.: Fused Deposition Modelling: Most Common 3D Printing Method; http://www.livescience.com/39810-fused-deposition-modeling.html (letöltve: 2018.05.03.)

[5] Additív technológiák körkép; http://www.cnc.hu/2012/12/additiv-technologiak-korkep/ (letöltve: 2018.05.03.)

[6] 3D printing Technology Comparision: SLA vs. DLP; https://formlabs.com/blog/3dprinting-technology-comparison-sla-dlp/ (letöltve: 2018.05.04.)

[7] 3D nyomtatás különbözö technológiákkal II. - Az SLS eljárás; https://3dnyomtato.wordpress.com/2013/08/14/3d-nyomtatas-kulonbozotechnologiakkal-ii-az-sls-eljaras/ (letöltve: 2018.05.05.)

[8] PACURAR R.; PACURAR A.: Applications of the Selective Laser Melting Technology in the Industrial and Medical Fields, 2016. DOI: 10.5772/63038 https://www.intechopen.com/books/new-trends-in-3d-printing/applications-of-theselective-laser-melting-technology-in-the-industrial-and-medical-fields (letöltve ideje: 2018.05.06.)

[9] What is 3D Printing? The definitive guide to additive manufacturing; https://www.3dhubs.com/what-is-3d-printing\#technologies (letöltve: 2018.05.07.)

[10] PALERMO, E.: What is Laminated Object Manufacturing?; http://www.livescience.com/40310-laminated-object-manufacturing.html (letöltve: 2018.05.07.)

[11] https://www.manufacturingguide.com/en/laminated-object-manufacturing-lom (letöltve: 2018.05.08.)

[12] GRUNEWALD, S. J.: What You Need to Know About 3D Printed Guns and Why You Don't Need to Fear them; https://3dprint.com/139537/3d-printed-guns/ (letöltve: 2018.06.08.)

[13] NEWMAN, J.: Solid Concepts Uses Metal Additive Manufacturing to Build a Gun; http://www.rapidreadytech.com/2013/11/solid-concepts-uses-metal-additivemanufacturing-to-build-a-gun/ (letöltve: 2018.06.08.)

[14] SAUNDERS, S.: US Army Successfully Tests 3D Printed Grenade Launcher with 3D Printed Grenades; https://3dprint.com/167567/3d-printed-grenade-launcher/ (letöltve: 2018.06.08.)

[15] MILLS, D. K.: Future Medicine: The Impact of 3D Printing, 2015. pp. 1-3.; https://www.researchgate.net/publication/281939684_Future_Medicine_The_Impact_of 3D_Printing (letöltve: 2018.05.09.) 
[16] VRIES, DE. C..: Open Bionics: 3D printed prosthetic limbs; https://ultimaker.com/en/stories/36096-open-bionics-3d-printed-prosthetic-limbs (letöltve: 2018.06.03.)

[17] Lágy robotika - , lágy robotok”; https://www.igus.hu/wpck/11989/softrobotics (letöltve: 2018.06.05.)

[18] GUL, J. Z.; SAJID, M.; REHMAN, M. M.; SIDDIQUI, G. U.; SHAH, I.; KIM, K-H; LEE, J-W; CHOI, K, H.: 3D Printing for soft robotics - a review; 2018. p. 3. https://www.tandfonline.com/doi/pdf/10.1080/14686996.2018.1431862?needAccess=tru $\underline{e}$ (letöltve: 2018. 06. 05.)

[19] SUN, J; PENG, Z.; YAN, L; FUH, J. Y. H.; HONG, G. S.: 3D food printing - An innovative way of mass customization in food fabrication; 2015. pp. 1-12.;

http://ijb.whioce.com/index.php/int-j-bioprinting/article/view/01006/pdf_5 (letöltve: 2018.06.05.)

[20] https://www.thefoodrush.com/articles/3d-printing-food-for-an-entire-restaurant-menu/ (letöltve: 2018. 06. 05.)

[21] GAGET, L.: 3D printed shoes: How 3D printing revolutionizes the footwear industry; https://www.sculpteo.com/blog/2017/10/31/3d-printed-shoes-how-3d-printingrevolutionize-the-footwear-industry/ (letöltve: 2018. 06. 06.)

[22] 3D printing and new structures within the textile industry; https://www.sculpteo.com/en/applications/textile-industry/ (letöltve: 2018.06.06.)

[23] Nyomtatott lövedékek; http://freedee.blog.hu/2016/11/15/nyomtatott lovedekek\#more11959853 (letöltve: 2018.06.07.)

[24] Russia uses 3D printing in production of colossal T-14 Armata tank; www.3ders.org/articles/20160208-russia-uses-3d-printing-in-production-of-colossal-t14-armata-tank.html (letöltve: 2018.06.07.)

[25] Russian 3D printed microsatellite Tomsk-TPU-120 successfully launched from Baikonur launch site; http://www.3ders.org/articles/20160401-russian-3d-printed-microsatellitetomsk-tpu-120-successfully-launched-from-baikonur-launch-site.html (letöltve: 2018.06.07.)

[26] DUBOIS, T.: How Will 3-D Printing Rearrange The Aerospace Spare Parts Business?; http://www.mro-network.com/emerging-technology/how-will-3-d-printing-rearrangeaerospace-spare-parts-business (letöltve: 2018.06.07.)

[27] WU, S-Y.; YANG, C.; HSU, W.; LIN, L.: 3D-printed microelectronics for integrated circuitry and passive wireless sensors; 2015. p. 1.; https://www.nature.com/articles/micronano201513.pdf (letöltve: 2018. 06. 10.)

[28] FLOWERS F. P.; REYES, C.; YE, S.; KIM, J. M.; WILEY, J. B.: $3 D$ printing electronic components and circuits with conductive thermoplastic filament; 2017. p. 4.; http://people.duke.edu/ bjw24/Publication86.pdf (letöltve: 2018. 06.11.)

[29] HÖRBER, J.; GLASSCHRÖDER, J.; PFEFFER, M.; FRANKE, J.: Approaches for Additive Manufacturing of 3D Electronic Applications 2014. p. 807.; https://www.researchgate.net/publication/273876153_Approaches_for_Additive_Manuf acturing_of_3D_Electronic_Applications (letöltve: 2018. 06.12.) 
[30] FÜZES L.: Új lehetőségek a villamosiparban a müszaki müanyagok és az additív technológiák számára; http://www.muanyagipariszemle.hu/2016/01/uj-lehetosegek-avillamosiparban-a-muszaki-muanyagok-es-az-additiv-technologiak-szamara-11.pdf (letöltve: 2018. 06.12.)

[31] https://www.optomec.com/printed-electronics/aerosol-jet-technology/ (letöltve: 2018.06.12.)

[32] https://www.optomec.com/printed-electronics/aerosol-jet-core-applications/printedantennas (letöltve: 2018.06.12.)

[33] http://importantevents24.com/wp-content/uploads/2017/10/global-aerosol-jet-printingmachine-market.jpg (letöltve: 2018.06.18.)

[34] GARCIA, C.R; RUMPF, R. C; TSANG, H. H.; BARTON, J. H.: Effects of extreme surface roughness on $3 D$ printed horn antenna; 2013. pp. 1-3; http://ieeexplore.ieee.org/stamp/stamp.jsp?arnumber=6550127 (letöltve: 2018.06.18.)

[35] COPPER MOUNTAIN TECHNOLOGIES: Design and Test a 3D Printed Horn Antenna, pp.1-3.; https://coppermountaintech.com/design-test-a-3d-printed-hornantenna/ (letöltve: 2018.06.18.)

[36] GOH, G. D; AGARWALA, S.; GOH, G. L; DIKSHIT, V.; SING, L. S; YEONG, W.Y.: Additive manufacturing in unmanned aerial vehicles (UAVs): Challenges and potential; 2017. p. 3.; https://www.sciencedirect.com/science/article/pii/S127096381630503X (letöltve: 2018.06.18.)

[37] GOLSON, J.: A military-grade drone that can be printed anywhere; https://www.wired.com/2014/09/military-grade-drone-can-printed-anywhere/ (letöltve: 2018.06.18.)

[38] MURASKIN, E.: How IoT and 3D printing are changing the connected space; http://internetofthingsagenda.techtarget.com/feature/How-IoT-and-3D-printing-arechanging-the-connected-space (letöltve: 2018.06.18.)

[39] http://www.optomec.com/printed-electronics/aerosol-jet-emergingapplications/military-aerospace/ (letöltve: 2018.06.18.)

[40] MAIN, D.: 4D Printing May Bolster Arsenal of US Army; http://www.livescience.com/40888-army-4d-printing-grant.html (letöltve: 2018.06.19.) 